\title{
The Date of KĀLIDĀSA
}

By reference to the description in the Raghuvamsa of the military expedition of Raghu against the Hunns, the earliest and the lowest limits of the time during which Kālidāsa flourished have been approximately fixed by many learned scholars. The accounts which we get of the movements of the Ephthalites render it highly improbable that Kālidāsa could have flourished earlier than the fifth century of the Christian era: But it appears to me extremely doubtful whether the state of things disclosed by the poet in his description can justify us in placing him in the time of Yasodharman.

The main proposition of Dr. Hoernle (JRAS., 1909, pp. 89-144), that the Śakāri-Vikramāditya, with whom the Mâlava era is associated in the popular tradition of India, is no other than Yaśodharman, has been, in my humble opinion, very ably propounded and established. My contention is only in respect of a corollary regarding the time of Kālidāsa.

Anticipating as it were the suggestion of Dr. Hoernle, I scrutinized some time ago very carefully the writings of Kālidāsa to find out if there be any mention, by way of pun or otherwise, of any persons or incidents of historical note. It is the result of this investigation that I publish now to show that Kälidàsa could not be the court poet of Yasodharman, and that the former must have preceded the latter. I shall set forth some historical facts first, and shall then show that we find them mentioned in the works of the poet.

1. However extensive the conquests of Yasodharman may have been, that he, born in the country of Maru (Mālava), was known principally as the mighty king of Ujjayini, is amply proved by the very documents which have been adduced by Dr. Hoernle to make out his case. We learn also from his Mandasor inscription that 
Yaśodharman, far from acknowledging the overlordship of the Imperial Guptas, most openly defied their authority.

It must again be noted regarding the Imperial Guptas that during their prosperous times they had at Puspapura (no matter whether it is Pátaliputra or not) a royal residence (F.GI., pp. 5, 6). From the information which we can gather from the Purānas, we can say that though they had now this town and now another for their capital, these Guptas were regarded in local consideration as the lords of Magadha. On reference to the list of countries conquered by Samudra Gupta, we can see that excepting the Magadha-deśa all other countries are mentioned as annexed to his kingdom. Even though they were overlords, the Imperial Guptas were "Magadheśvaras".

Bearing these historical facts in mind, let us refer to stanzas 20-36 of the 6th canto of Raghuvamisa. In the assembly of the Rājās of all India, the "Magadheśvara" is described in very clear and unmistakable words as the overlord in India (vi, 22). It is for this reason that Indumati approaches him first (vi, 20); and though she does not elect him as her husband, she bows down to $\operatorname{him}(v i, 25)$ to do the honour specially due to the overlord of the country. The name of the capital of this overlord is given as Puspapura (vi, 24), the very name which we meet with in the inscription just referred to. The mention of continual celebration of the Vedic sacrificial rites in the 23rd stanza is of much importance, for we know that the Imperial Guptas have repeatedly mentioned in all their records that they restored the Vedic rites of sacrifice which had been long in abeyance.

I should also mention in this connection that though we do not find either in the Rāmāyana or in the old Purānas, that the Rājā Dilipa celebrated any Aśvamedha, yet this is a special subject for the delineation of the poet in the 3rd canto of the Raghuvamsa. It is also evident that the poet alluded to the lords of Magadha 
of his time, for neither according to the Rāmāyana, nor consistently with the poet's own statement of the unrivalled supremacy of the Rājās of Kosala in the lst canto, could the lords of Magadha be described as overlords in India when Aja married Indumati.

The Rājā of Ujjayinī is only third on the list (vi, 31), while Anga-rāja, belonging very likely to the Licchavi family, is second. Of the "Sāmanta" Rājās, no doubt the Rājā of Ujjayini is described as the leader (vi, 33); but all the same he is but a "star" before the moon (vi, 22). Could such description be pleasing to Yaśodharman, who declared himself superior to the Imperial Guptas? Even if it be conceded that Kälidāsa flourished in his time, it cannot be said that Kälidäsa was the court poet of Yaśodharman.

2. We get the name of $S_{r} \bar{\imath}$-Gupta as the first Rājā of the Imperial Guptas. The first Rājā of the kings of the Solar family has been described in the Raghuvamisa by the words Pranavaś chandasām iva (i, 11). Pranavah, as is well known, is represented by one compound letter $O \dot{m}$. The name of the first Rãja of the Guptas is also required to be written by one compound letter Śri

Clearer becomes the reference when we come across the words $\bar{A}$ samudraksitis $\bar{x} n \bar{a} m$ (i, 5). Those who became ksitisas (lords of the world) from the time of Samudra (i.e. Samudra Gupta) may be another meaning of the words. That a pun was intended by the poet is evident from the following fact:-Asamudraräjya, or a phrase similar to that, would be the usual expression according to grammar and idiom. This construction, namely, the lords of the ksiti which is $\vec{a} s a m u d r a$, or extended to the seas, is rather roundabout, though quite correct. We know that it was from the time of Samudra Gupta that the Gupta emperors assumed the title Mahārājādhirāja, and thus we can discover the allusion easily. 
We then notice the line Ditīpa iti rājendur induh leşiranidhā $v$ iva (i, 12). Like Indu (i.e. Candra or moon) from the kṣiranidhi (i.e. Samudra or sea), it suggests the name of Candra Gupta II, son of Samudra Gupta.

The words kumārajanma (iii, 16) and kumāro 'pi Kumāravikramah (iii, 55), with reference to Raghu, son of Dilipa, point perhaps by way of pun to Kumāra Gupta I, for he is also said to have derived his lustre from the sun (Vikramāditya), like a Bāla-Candramāh (iii, 22). The words $\bar{a}$-kumāra-kathodghătam, etc. (iv, 20), are similar in meaning and almost in form with what we read in the 12th line of the Bhițāri inscription (F.GI., p. 54). Again, the words Śriyam Mahendranāthasya jahāra seem to allude to the title Mahendrāditya of Kumāra Gupta I (iv, 43).

Then again, with reference to the birth of Aja, it has been said that the queen of Raghu delivered (suşuve) a Kumāra (son) who was Kumāra-kalpa (like Kumāra himself) (v, 36). The pun is quite complete here, for Kumāra and Skanda are the names of one god.

If all that I have stated be not considered untenable, can it not also be supposed that the work Kumārasambhava was so entitled with a view to please or humour the Rājā Kumāra Gupta I? There is a special reason for offering this suggestion. It was believed in the olden days, as we learn from the works on rhetoric, that the composition of a Mahākāvya had the effect of removing and avoiding diseases and calamities. If, however, during the composition of such a work any new disaster befell, the work might be considered to be inauspicious. We know that Kumāra Gupta met with some reverses, and Skanda Gupta (then a Yuvaräja) had to restore the family glory. It is not unlikely that for some such reason the completion of the Kumārasambhava was abandoned, and some choice stanzas of that work (vii, 56-67), as might be fittingly introduced, were 
inserted subsequently in the Raghuvamśa (vii, 5-16). I need hardly mention that Kālidāsa is the author of only the first seven cantos of the Kumārasambhava.

Following thus in regular order the names of the Imperial Guptas, when we come upon the line Skandena săkșād iva Devasenām (Raghuvamśa, vii, 1), in the description of the happy union of Aja and Indumati, we are inclined to regard it as an allusion to Skanda Gupta.

3. Let us suppose, just for the sake of a theory, that Kālidāsa commenced his career as a poet when quite a young man during the last decade of the reign of Kumāra Gupta I (say, by about 445 A.D.), and died a few years after the death of Skanda Gupta. We may proceed then to test the possibility of it by the facts which we may gather from the works of the poet.

I have already suggested a reason for the unfinished condition of the Kumärasambhava. I consider next a point of some importance regarding the purpose which Kālidāsa had in view when he commenced the composition of the Rughuvamía. It has been stated in the introductory portion of the poem that the poet would sing the unmixed glory of the heroes he undertook to describe (i, 2-9). But the subsequent development of the poem shows another state of things. From the 16th to the 19th canto the decline and fall of the Kosala Rājās has been depicted. Lakṣmī (the goddess of good luck) grew restless when a partition of the kingdom was effected. The pitiable condition of the empire as described by the goddess may be easily imagined to be the exact picture of what took place at the death of Skanda Gupta when the Hūns became powerful (xvi, 1-22).

Consistently with the original purpose of the poet as declared in the beginning of the 1st canto, the poem perhaps ended with the 15th as the last canto where the career of the ideal hero Ràma comes to an end. Cantos xvi to xix may have been added subsequently 
to impart some wholesome advice to the unworthy successor or successors of the departed Mahārāja, when a gloom was cast over the whole country.

We know that after the death of Skanda Gupta one branch of the family commenced to reign in the eastern country, while another branch was exercising its influence over the tract lying between the Kălindi and the Narmad̄̄ (F.GI., p. 89). The partition mentioned by the poet in the 16th canto refers very likely to such a state of things, for in the word purojanmatay $\bar{a}$ of the 1st stanza the name of Pura Gupta seems to be suggested.

4. We are not in possession of any definite information regarding the Pusyamitras who had to be subdued by Skanda Gupta when he was Yuvarāja. In view of the political condition of India in those days, it may be supposed that troubles came from or arose in Mălava. It might be that when Skanda Gupta was Yuvarāja he had to stay for some time in Mālava to quell some disturbance. It is a supposition merely, but I seek to connect with it the stanza of the Meghaduta (pt. i, 47), ${ }^{1}$ wherein the cloud is asked to shed flowers and holy water on the head of Skanda while going to Daśapura from Ujjayini. Stcanda is there said to have been stationed by his father to subdue the enemies.

5. I now examine the accounts of the military expedition of Raghu against the Hūns. Whatever may be the true interpretation of the passage in the Kathasaritsāgara (T.KS., ii, $563 \mathrm{ff}$.), there is no doubt of the fact that during the early years of his reign Skanda Gupta had come in contact with the Hūns before the latter conquered Gāndhāra (F.GII, p. 56). Even if as a matter of fact Skanda Gupta did not make any such expedition as a digvijaya, a poet admiring him for his success in the conflict with the Pusyamitras and the Hūns may invent

1 The edition of G. R. Nandargikar is referred to. In other editions this is the 44th stanza of the Pūrva-Megha. 
a digvijaya for him. The only thing we have carefully to consider is whether the description of the poet is consistent with the state of things of the time of Yasodharman.

When, during the last days of the reign of Bāladitya, Yaśodharman defeated Mihirakula, the Hūns had their settlement in India proper, and the town of Siālkot was the capital of Mihirakula. But the Hūns are described by Kālidāsa as foreigners like the Persians, and Raghu's soldiers had to proceed farther north (kauverim diśam), after having defeated the Persians, to meet the Hūṇs in their own land (iv, 66--68). As Kambojas were conquered next in the neighbourhood of the country possessed by the Hūns (iv, 69), the Hūṇs had not become by that time the lords of Gāndhāra. The Bhitāri inscription proves clearly that even before the Hūns acquired supremacy over Gāndhāra, Skanda Gupta had to fight against them.

6. It remains to be seen whether Dignāga, the famous disciple of Vasubandhu, could be a contemporary of Kālidāsa, if for the literary career of Kālidāsa, who produced so many works, a period of thirty-five years, from 445 to 480 , be assigned.

Without going into minor details in respect of dates, it may be asserted on the authority of Dr. Takakusu (JRAS., 1905, $33 \mathrm{ff}$.) that Vasubandhu was very old when Skanda Gupta was the emperor of Northern India. This fact is alone sufficient to show that what Mallinātha writes in his commentary in the thirteenth century A.D. on the 14th stanza of the Meghaduta can be easily reconciled with the date set forth above. As Dr. Takakusu accepted wrongly the year 480 A.D. as the date of Skanda Gupta's death, he set down $420-500$ as the whole lifetime of Vasubandhu. Vasubandhu, who was very old when Skanda Gupta was reigning, and died only a short time after Bāläditya had ascended the throne, cannot be supposed to have died twenty years after 480 A.D. Conceding the date 480 to be the correct 
time when Skanda died, the date of Vasubandhu's death cannot be later than 485 . In that case Vasubandhu was. 40 years old in 445 . The disciple of his, who was very intelligent, can be taken to be younger than him only by ten years or thereabout. Dignāga can be imagined to have been a grown-up man of some fame when Kālidāsa. composed his Meghadūta.

Let me, however, consider carefully as to the exact date of Skanda Gupta's death. When a loyal governor of the Guptas at Dasapura recorded the fact of some repairs. having been done to a temple originally built during the time of Kumāra Gupta I, he did not fail in his loyalty to mention the name of Kumära Gupta in 472 A.D. (F.GI., pp. 79-84). Could it be possible for such a loyal governor to omit the name of Skanda Gupta (even though the latter might have been reduced to insignificance) if he were then alive? Merely because no epigraphic record can be found of the successor of Skanda Gupta earlier than 480, it cannot be held that Skanda Gupta lived till that. date. It is difficult to believe that Skanda Gupta Vikramāditya was transformed into Pura Gupta Prakāsāditya (JRAS., 1909, p. 129).

The plate of Bandhuvarman just referred to discloses also the fact that many other Rājās became powerful since the time of Kumāra Gupta I (F.GI., p. 83, l. 20). What this means we can understand by reference to the then rising power of the Hūns, and also with reference to F.GI., p. 89, which informs us that the tract of the country lying between the Kālindi and the Jamnā came under the rule of one who was in some way or other connected with the Gupta family.

It is pretty certain that Skanda Gupta died without leaving any male issue. In that case he must have elected a son of his brother (as was, and is still, customary in India) as his successor, and made him a crown prince. Possibly Pura Gupta, taking advantage of the situation, 
himself became the king. It may also be possible that Pura Gupta and Bālàditya commenced to rule the eastern countries simultaneously by splitting up the kingdom, as is expressed by Kālidāsa by the words bhinno'stadhā viprasasāra variśah (Raghuvariśa, xvi, 3).

Thus, as in 472 A.D. the duly elected successor of Skanda Gupta did not become supreme over Mālava, the loyal governor of the Guptas at Daśapura had reasons not to mention the name of any overlord when the temple was repaired.

Skanda Gupta then must have died some time between 468 and 472 A.D. According to this calculation the date of Vasubandhu's death must be fixed at about 480 . Readjustment of these dates has become very necessary, and scholars like Dr. Fleet and Dr. Hoernle may be requested to undertake the task.

7. I must mention another fact before I conclude. Kālidāsa does not appear to have been the court poet of any Rājā at all. He must have earned a good deal by writing his works, and by being rewarded by the Imperial Guptas. He seemed to have lived principally at Ujjain, where he composed his drama Śakuntala. He did not dedicate this drama to any Rājā, but presented it for being enacted at the local festival of the god Mahākāla. It may be that during his last days the poet became very closely associated with the Imperial Guptas.

When the poet commenced to compose the Raghuvamisa he must have had the Imperial Guptas in view; for, had his subject been only the ancestors of Rāma, he would not have stated that his imagination was fired by hearing only the glorious deeds of the heroes, and not by reading them. Tad-gunaih karnam āgatya cappalāya pracoditah is the line in the Introduction (i,9). This also shows that the poet lived far away from the capital of the Guptas, though he was attached to the Rajjās.

B. C. Mazumdar. 